\title{
A modified automated protocol for EBER in situ hybridization staining of xenograft tissue
}

\author{
AZIZ, N. A. *, AHMAD, M. and SOO-BENG KHOO, A. \\ Molecular Pathology Unit, Cancer Research Centre - CaRC, Institute for Medical Research - IMR, Jalan Pahang, \\ 50588, Kuala Lumpur, Malaysia \\ *E-mail: norazlin@imr.gov.my
}

\begin{abstract}
Introduction: Epstein-Barr virus encoded RNA (EBER) in situ hybridization (ISH) is a method for the identification of Epstein-Barr virus (EBV) infection in tissue sections. In our experience, the currently available automated EBER ISH staining protocol using the Bond-Max immunostainer is not suitable for xenograft tissue sample due to high background staining which impairs the interpretation of the staining. Methods: Here we describe a modified automated EBER ISH staining protocol for xenografts which involves the substitution of reagents for detecting the EBER probe. Results: This modified protocol significantly improved the quality and speed of the staining. Conclusion: The method described here will be useful for EBER ISH staining of xenograft tissue samples.
\end{abstract}

Keywords: Epstein-Barr virus, EBER, in situ hybridization, xenograft.

\section{Introduction}

$\mathrm{EBV}$ is among one of the viruses which is classified as carcinogenic. It is known to be highly associated with human cancers such as Burkitt's lymphoma and nasopharyngeal carcinoma (SARID and GAO, 2011). EBV-positive cancers have been shown to be associated with the latent phase infection of the virus which can be further classified into latency type I, II and III depending on the gene expression pattern (KANG and KIEFF, 2015; THOMPSON and KURZROCK, 2004).

EBERs (EBER-1 and EBER-2) are small, non-coding RNAs, which are expressed in all forms of EBV latent infections, making them a sensitive target for the detection of EBV infection (IWAKIRI and TAKADA, 2010; KHAN, COATES, KANGRO et al., 1992). EBER ISH is widely accepted as a gold standard test to detect latent EBV infection in tissue sections (GULLEY, 2001; GULLEY and TANG, 2008). This method allows the identification of EBV in tissue sample by utilizing a specific probe which targets the EBER transcripts in latently infected cells of the tissue sections.

EBER ISH is routinely performed as a chromogenic ISH (CISH) whereby an immunoenzymatic technique is used for visualization of the labelled target. Currently, we are using the Bond Polymer Refine Detection kit (Leica Microsystem) on a Bond-Max immunostainer (Leica Microsystem) to perform fully automated EBER ISH which allows processing of 30 slides per run. In principle, fluorescein (FITC)-conjugated oligonucleotide probes which binds to the EBER transcripts (target RNA) (Figure 1A, B) in the tissue sections were detected using a pre-diluted mouse anti-FITC antibody (Figure 1C). Using Bond Polymer Refine Detection system, this antibody is detected using rabbit anti-mouse antibody (post primary) (Figure 1D). Next, a polymer system which consists of horseradish peroxidase (HRP) polymer conjugated anti-rabbit antibody is used to detect the post primary reagent (Figure 1E). Finally, 3,3' diaminobenzidinetrahydrochloride
$(\mathrm{DAB})$ is used as a substrate-chromogen to visualize the localized targets, which appear as brown end products.

In order to perform a fully automated EBER ISH staining, we initially followed the standard protocol (ISH A) which was optimized by the manufacturer for human tissue samples. However, we noticed high non-specific background staining when we applied the same protocol for our xenograft tissue samples, which were tumour tissue or cancer cell lines of human origin grown in mice. This was due to cross-reactivity of the reagents in the detection system with the mouse immunoglobulins which impaired the interpretation of the staining. The aim of this paper is to describe an improved fully automated staining protocol for EBER ISH immunostaining on xenograft tissue samples.

\section{Materials and Methods}

Tissue sections were prepared from formalin-fixed, paraffin-embedded (FFPE) xenograft tissue of nasopharyngeal carcinoma cell lines, $\mathrm{Cl} 7$ and $\mathrm{HKl}$, grown in immunodeficient NOD-scid gamma (NOD.Cg-Prkdc scid $\mathrm{Il} 2 \mathrm{rg}^{\mathrm{tm} l W_{j l}} / \mathrm{SzJ}$ ) mice. $\mathrm{Cl7}$ is an EBV positive nasopharyngeal carcinoma cell line (BUSSON, GANEM, FLORES et al., 1988) and HKl is an EBV negative nasopharyngeal carcinoma cell line (HUANG, HO, POON et al., 1980). All mice were housed, maintained and used in accordance with the institutional guidelines and protocols which were approved by the Animal Care and Use Committee (ACUC), Ministry of Health, Malaysia.

Details for equipment setup and reagents used are listed in Table 1.

Xenograft tissue samples which have been processed into FFPE tissue blocks using standard fixation and embedding techniques were sectioned at $3 \mu \mathrm{m}$ thickness, prepared on positively charged slides (Leica Bond Plus Slides, Leica Microsystems) and assigned for specific probes for testing. 


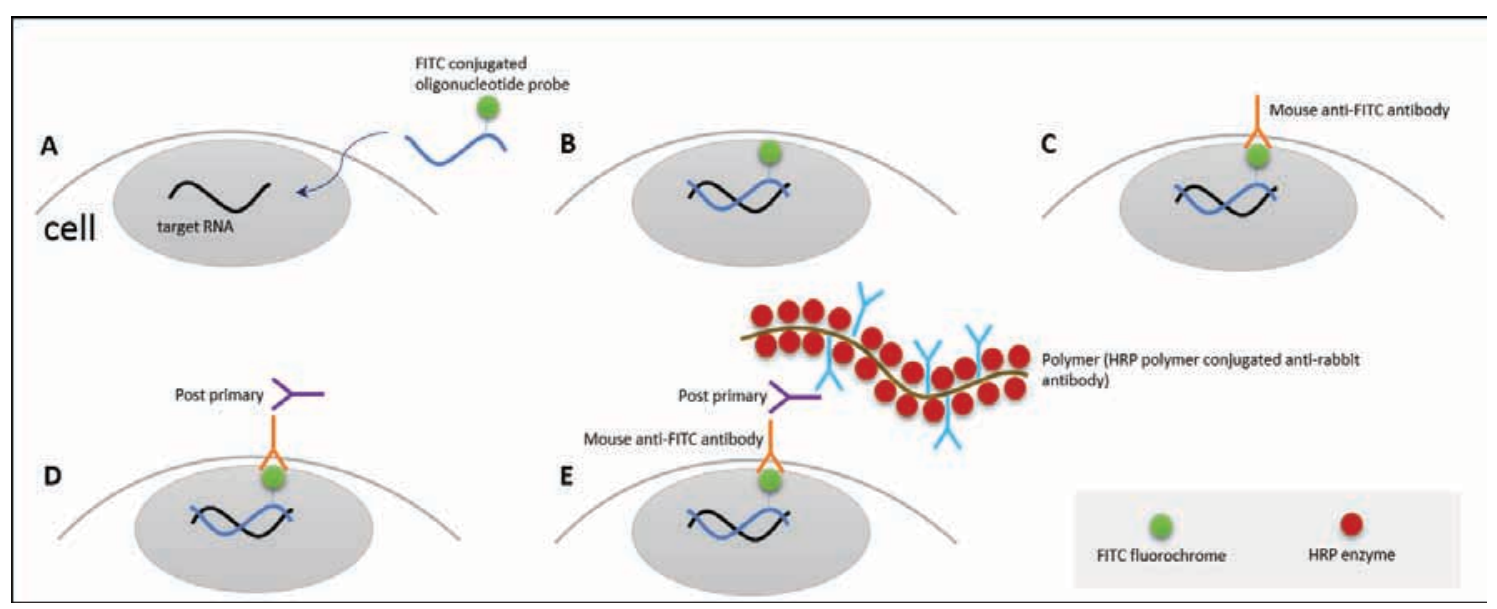

Figure 1. Steps involved in chromogenic ISH using Bond Polymer Refine Detection. (A, B) Target RNAs are labelled with FITC conjugated oligonucleotide probe; (C) Mouse anti-FITC antibody is used to label FITC conjugated probe; (D) Post primary is used to label mouse anti-FITC antibody; (E) HRP-polymer is used to label post primary.

Table 1. List of equipment setup and reagents.

\section{Equipment setup}

Bond-Max Immunostainer with research module (Leica Microsystems)

Bond Slide Tray (Leica Microsystems)

Bond Universal Covertile (Leica Microsystems)

Bond Titration Container (Leica Microsystems)

Bond Titration Container Inserts (Leica Microsystems)

Bond Reagent Tray (Leica Microsystems)

\begin{tabular}{l} 
Reagents \\
\hline Bond Polymer Refine Detection (Leica Biosystem, DS9800) \\
Bond ready-to-use ISH EBER Probe (Leica Biosystem, PB0589) \\
Bond ready-to-use ISH RNA Positive Control Probe (Leica Biosystem, PB0785) \\
Bond ready-to-use ISH RNA Negative Control Probe (Leica Biosystem, PB0785) \\
Bond ready-to-use Primary Antibody Anti-Fluorescein antibody (Leica Biosystem, AR0833) \\
Polyclonal Rabbit anti-FITC/HRP (DAKO, 1:50, P5100) \\
Bond Enzyme Pretreatment Kit consist of Bond Enzyme Concentrate (Proteinase-K) and Bond Enzyme Diluent (Tris- \\
buffered saline) (Leica Biosystem, Enzyme 1 concentration, AR9551) \\
DAKO Antibody Diluent (DAKO, S0809) \\
Bond Wash Solution 10x Concentrate (Leica Biosystem, AR9590) \\
Bond Dewax Solution (Leica Biosystem, AR9222) \\
Absolute ethanol (Merck Millipore, 1009832511)
\end{tabular}

The protocol described here is based on the ISH A protocol by the manufacturer which have been modified and optimized for EBER ISH staining of xenograft tissue samples and was designated as protocol ISH A-X. This protocol involves step elimination and substitution of reagents for detecting the EBER probe. As represented in Figure 2, fluorescein (FITC)-conjugated oligonucleotide probes which binds to EBER transcripts (target RNA) were directly labelled with HRP-conjugated anti-FITC antibody.

The complete procedures for this protocol were summarized in Table 2.

After staining, samples were dehydrated by passing in $2 \mathrm{x}$ changes of absolute alcohol ( $1 \mathrm{~min}$ ), followed by clearing in xylene ( $3 \mathrm{~min}$ ) and finally, the slide samples were mounted with cover slips using mounting media. All images were captured using a Nikon ECLIPSE Ti-E microscope (Nikon Instruments, Tokyo, Japan) equipped with 12-bit colour camera QICAM Color
Fast 1394 (QImaging, Surrey, Canada) and image acquisition software NIS Elements (version 4.2, Nikon Instruments).

Staining of tissue sections were assessed by evaluating the expression of the probes. Firstly, RNA integrity was assessed based on the expression of RNA Positive Control probe. Next, tissue sections hybridized with RNA Negative Control Probe were assessed for non-specific probe hybridization. Lastly, tissue sections were assessed for EBER positivity.

\section{Results and Discussion}

Based on the results, tissue samples which were hybridized with RNA Positive Control Probe showed positive staining for both protocol (Figure 3A, E). This indicate that the samples have well-preserved RNA.

Tissue samples hybridized with RNA Negative Control Probe and stained following ISH A protocol showed high non-specific background staining (Figure 3B). In contrast, 


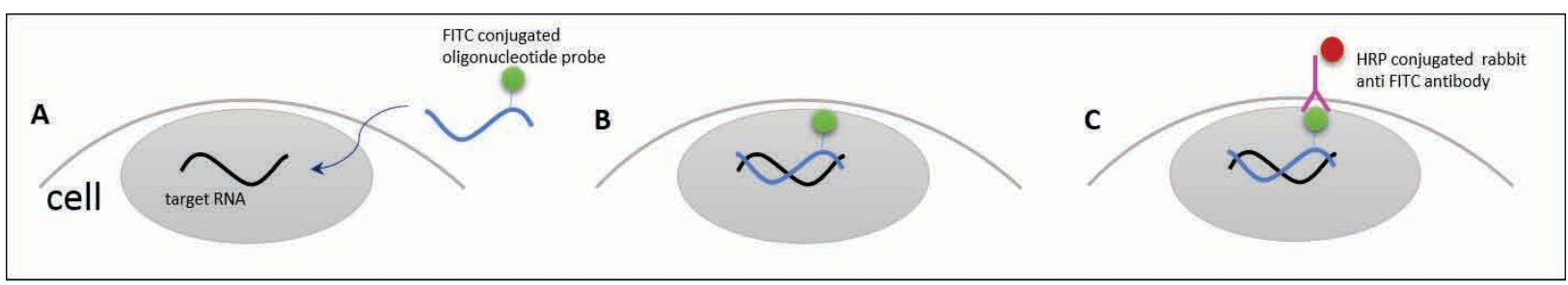

Figure 2. Modified protocol for EBER ISH. (A, B) Target RNAs are labelled with FITC conjugated oligonucleotide probe; (C) HRP conjugated rabbit anti-FITC antibody is used to label FITC conjugated oligonucleotide probe.

Table 2. Procedures for ISH A and ISH A-X protocols.

\begin{tabular}{|c|c|c|}
\hline & ISH A & ISH A-X \\
\hline Pre-treatment step & $\begin{array}{l}\text { 1. Baking }\left(60{ }^{\circ} \mathrm{C}, 30 \mathrm{~min}\right) \\
\text { 2. Dewaxing }\left(2 \mathrm{x} \text { at } 72^{\circ} \mathrm{C}, 1 \mathrm{x} \text { at ambient temp }\right. \\
\text { 3. Rehydration }(3 \mathrm{x} \text { with absolute alcohol, } 4 \mathrm{x} \text {. } \\
\text { 4. Enzymatic retrieval (Enzyme } 1 \text { solution, } 37 \\
\text { temperature). }\end{array}$ & $\begin{array}{l}\text { ature). } \\
\text { Nash solution at ambient temperature). } \\
\text { C, } 10 \mathrm{~min}, 3 \mathrm{x} \text { of wash solution at ambient }\end{array}$ \\
\hline Hybridization & $\begin{array}{l}\text { 5. Hybridization with probe }\left(37^{\circ} \mathrm{C}, 2 \mathrm{~h}\right) \\
\text { 6. Post hybridization washing }(10 \mathrm{x} \text { of wash so }\end{array}$ & ion at ambient temperature). \\
\hline Peroxidase blocking & 7. Peroxide block $(1 \mathrm{x}, 5 \mathrm{~min}, 3 \mathrm{x}$ wash solution & t ambient temperature). \\
\hline \multirow{3}{*}{ Detection } & $\begin{array}{l}\text { 8. Anti-FITC antibody (Leica Biosystem) } \\
(1 \mathrm{x}, 15 \mathrm{~min}, 3 \mathrm{x} \text { wash solution at ambient } \\
\text { temperature). }\end{array}$ & $\begin{array}{l}\text { 8. Anti-FITC/HRP antibody (DAKO) } \\
(1 \mathrm{x}, 20 \mathrm{~min}, 4 \mathrm{x} \text { wash solution, } 1 \mathrm{x} \\
\text { deionized water at ambient temperature). }\end{array}$ \\
\hline & $\begin{array}{l}\text { 9. Post Primary ( } 1 \mathrm{x}, 8 \mathrm{~min}, 3 \mathrm{x} \text { wash solution } \\
\text { at ambient temperature). }\end{array}$ & omitted \\
\hline & $\begin{array}{l}\text { 10. HRP-Polymer ( } 1 \mathrm{x}, 8 \mathrm{~min}, 2 \mathrm{x} \text { wash } \\
\text { solution, } 1 \mathrm{x} \text { deionized water, at ambient } \\
\text { temperature). }\end{array}$ & omitted \\
\hline Chromogen visualization & $\begin{array}{l}\text { 11. DAB ( } 10 \text { min, } 3 \mathrm{x} \text { wash solution at } \\
\text { ambient temperature). }\end{array}$ & $\begin{array}{l}\text { 9b. DAB ( } 8 \text { min, } 3 \mathrm{x} \text { wash solution at } \\
\text { ambient temperature }) \text {. }\end{array}$ \\
\hline Counterstaining & \multicolumn{2}{|c|}{$\begin{array}{l}\text { Haematoxylin ( } 5 \text { min followed by final wash in a sequence of } 1 \mathrm{x} \text { deionized water, } 1 \mathrm{x} \text { wash } \\
\text { solution and } 1 \mathrm{x} \text { deionized water). }\end{array}$} \\
\hline
\end{tabular}

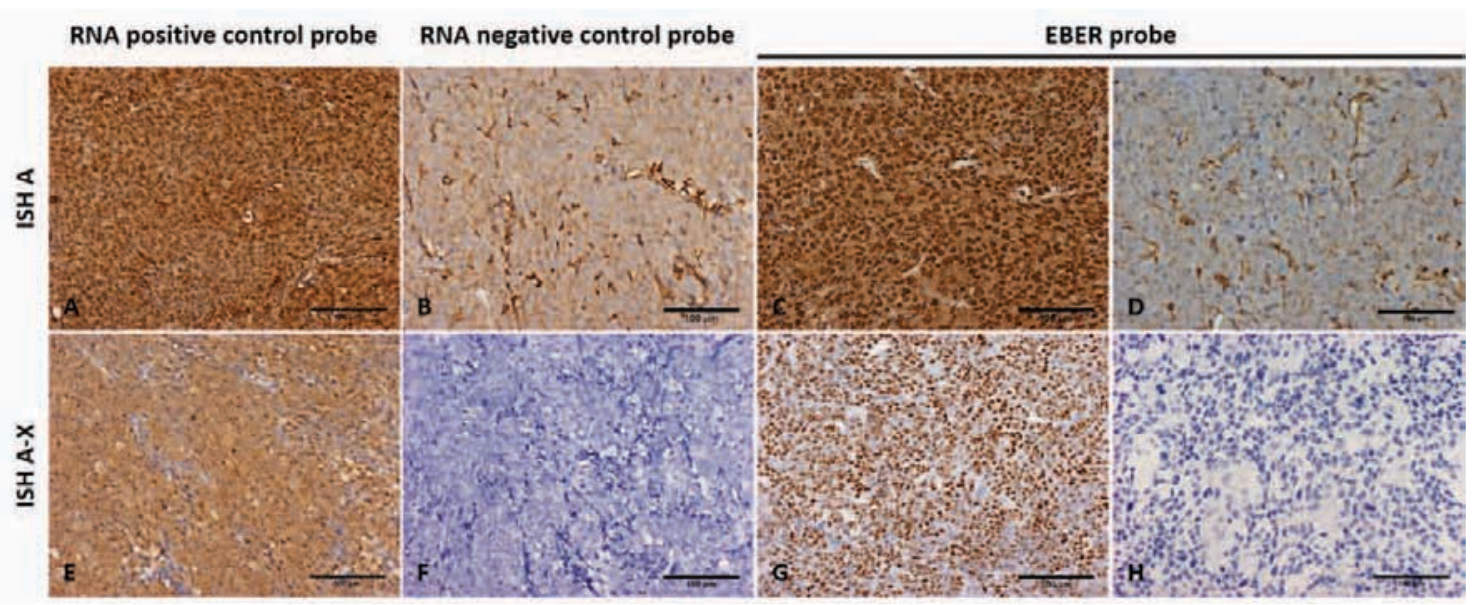

Figure 3. Example of xenograft tissue sections stained using ISH A and ISH A-X protocol. (A-C) Cl7 xenograft tissue sections stained using ISH A protocol; (D) HKl xenograft tissue section stained using ISH A protocol; (E-G) C17 xenograft tissue sections stained using ISH A-X protocol; (H) HKI xenograft tissue section stained using ISH A-X protocol.

tissue samples stained following ISH A-X protocol showed absolute negative staining with no background staining observed (Figure 3F).

EBV positive tissue samples hybridized with EBER Probe showed positive staining for both staining protocol (Figure 3C, G). However, it was noted that tissue sample stained following ISH A protocol showed high non-specific background staining making positive interpretation of the staining difficult (Figure 3C). In addition, EBV negative xenograft tissue (HKl) also showed high non-specific background staining which may lead to false positive interpretation (Figure $3 \mathrm{D}$ ). On the contrary, tissue samples stained following ISH A-X 
protocol showed no background staining which results in excellent demonstration of EBV positive cells only (Figure 3G). EBV negative xenograft tissue stained with ISH A-X protocol also showed absolute negative staining with no background staining observed (Figure $3 \mathrm{H}$ ).

In conclusion, we described here an improved EBER ISH automated staining protocol for xenograft. This protocol involved substitution of reagents for detecting the EBER probe which has significantly improved the quality and speed of the staining. The method described here will be useful for EBER ISH staining of xenograft tissue sample of equivalence.

Acknowledgements: We thank the Director General of Health, Malaysia for his permission to publish this manuscript. We also thank the Director of the Institute for Medical Research for supporting this project. We would also like to acknowledge other staff members from Molecular Pathology Unit, IMR for their support. This work was funded by the Ministry of Health Malaysia. HKl was kindly provided by George Tsao (Department of Anatomy, Faculty of Medicine, University of Hong Kong, Hong Kong) and C17 by Pierre Busson (Gustave Roussy Institute, Villejuif, France).

\section{References}

BUSSON, P., GANEM, G., FLORES, P., MUGNERET, F., CLAUSSE, B., CAILLOU, B., BRAHAM, K., WAKASUGI, H., LIPINSKI, M. and TURSZ, T. Establishment and characterization of three transplantable EBV-containing nasopharyngeal carcinomas. International Journal of Cancer, 1988, vol. 42, n. 4, p. 599-606. PMid:2971626. http:// dx.doi.org/10.1002/ijc.2910420422.

GULLEY, ML. Molecular diagnosis of Epstein-Barr virus-related diseases. The Journal of Molecular Diagnostics, 2001, vol. 3, n. 1, p. 1-10. PMid:11227065. http://dx.doi.org/10.1016/S1525$1578(10) 60642-3$.
GULLEY, ML. and TANG, W. Laboratory assays for Epstein-Barr virus-related disease. The Journal of Molecular Diagnostics, 2008, vol. 10, n. 4, p. 279-292. PMid:18556771. http://dx.doi.org/10.2353/ jmoldx.2008.080023.

HUANG, DP., HO, JH., POON, YF., CHEW, EC., SAW, D., LUI, M., LI, CL., MAK, LS., LAI, SH. and LAU, WH. Establishment of a cell line $(\mathrm{NPC} / \mathrm{HKl})$ from a differentiated squamous carcinoma of the nasopharynx. International Journal of Cancer, 1980, vol. 26, n. 2, p. 127-132. PMid:6259064. http://dx.doi.org/10.1002/ ijc.2910260202.

IWAKIRI, D. and TAKADA, K. Role of EBERs in the pathogenesis of EBV infection. Advances in Cancer Research, 2010, vol. 107, p. 119-136. PMid:20399962. http://dx.doi.org/10.1016/S0065230X(10)07004-1.

KANG, MS. and KIEFF, E. Epstein-Barr virus latent genes. Experimental \& Molecular Medicine, 2015, vol. 47, n. 1, p. el31. PMid:25613728. http://dx.doi.org/10.1038/emm.2014.84.

KHAN, G., COATES, PJ., KANGRO, HO. and SLAVIN, G. Epstein Barr virus (EBV) encoded small RNAs: targets for detection by in situ hybridisation with oligonucleotide probes. Journal of Clinical Pathology, 1992, vol. 45, n. 7, p. 616-620. PMid:1325480. http:// dx.doi.org/10.1136/jcp.45.7.616.

SARID, R. and GAO, SJ. Viruses and human cancer: from detection to causality. Cancer Letters, 2011, vol. 305, n. 2, p. 218-227. PMid:20971551. http://dx.doi.org/10.1016/j.canlet.2010.09.011.

THOMPSON, MP. and KURZROCK, R. Epstein-Barr virus and cancer. Clinical Cancer Research, 2004, vol. 10, n. 3, p. 803-821. PMid:14871955. http://dx.doi.org/10.1158/1078-0432.CCR-0670-3.

Received August 25, 2015 Accepted August 22, 2017 